This is an electronic reprint of the original article. This reprint may differ from the original in pagination and typographic detail.

Author(s): Slyvka, Yu.; Goreshnik, E.; Veryasov, G.; Morozov, Dmitry; Luk'yanov, M.; Mys'kiv, M.

Title: $\quad$ The First Copper(I)-Olefin Complexes Bearing a 1,3,4-Oxadiazole Core : AlternatingCurrent Electrochemical Crystallization, X-ray Experiment and DFT Study

Year: $\quad 2017$

Version:

Please cite the original version:

Slyvka, Yu., Goreshnik, E., Veryasov, G., Morozov, D., Luk'yanov, M., \& Mys'kiv, M. (2017). The First Copper(I)-Olefin Complexes Bearing a 1,3,4-Oxadiazole Core :

Alternating-Current Electrochemical Crystallization, X-ray Experiment and DFT Study. Polyhedron, 133, 319-326. https://doi.org/10.1016/j.poly.2017.05.052

All material supplied via JYX is protected by copyright and other intellectual property rights, and duplication or sale of all or part of any of the repository collections is not permitted, except that material may be duplicated by you for your research use or educational purposes in electronic or print form. You must obtain permission for any other use. Electronic or print copies may not be offered, whether for sale or otherwise to anyone who is not an authorised user. 


\section{Accepted Manuscript}

The First Copper(I)-Olefin Complexes Bearing a 1,3,4-Oxadiazole Core: Alternating-Current Electrochemical Crystallization, X-ray Experiment and DFT Study

Yu. Slyvka, E. Goreshnik, G. Veryasov, D. Morozov, M. Luk'yanov, M. Mys'kiv

PII: S0277-5387(17)30408-4

DOI: http://dx.doi.org/10.1016/j.poly.2017.05.052

Reference: POLY 12671

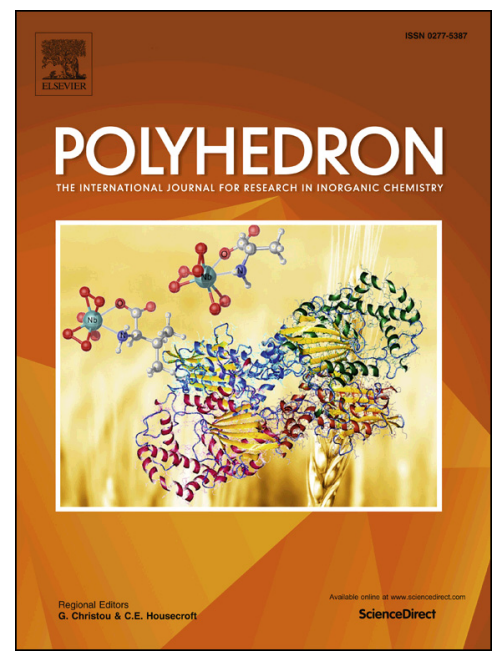

To appear in:

Polyhedron

Received Date:

16 March 2017

Revised Date:

12 May 2017

Accepted Date:

14 May 2017

Please cite this article as: Yu. Slyvka, E. Goreshnik, G. Veryasov, D. Morozov, M. Luk'yanov, M. Mys'kiv, The First Copper(I)-Olefin Complexes Bearing a 1,3,4-Oxadiazole Core: Alternating-Current Electrochemical Crystallization, X-ray Experiment and DFT Study, Polyhedron (2017), doi: http://dx.doi.org/10.1016/j.poly. 2017.05.052

This is a PDF file of an unedited manuscript that has been accepted for publication. As a service to our customers we are providing this early version of the manuscript. The manuscript will undergo copyediting, typesetting, and review of the resulting proof before it is published in its final form. Please note that during the production process errors may be discovered which could affect the content, and all legal disclaimers that apply to the journal pertain. 


\title{
The First Copper(I)-Olefin Complexes Bearing a 1,3,4-Oxadiazole Core: Alternating-Current Electrochemical Crystallization, X-ray Experiment and DFT Study
}

\author{
Yu. Slyvka ${ }^{\dagger}$, E. Goreshnik ${ }^{*}$,, G. Veryasov ${ }^{\ddagger}$, D. Morozov $^{\S}$, M. Luk’yanov ${ }^{\dagger}$ and M. Mys’kiv ${ }^{\dagger}$ \\ ${ }^{\dagger}$ Department of Inorganic Chemistry, Ivan Franko National University of Lviv, Kyryla i Mefodiya \\ Str., 6, 79005, Lviv, Ukraine \\ $¥$ Department of Inorganic Chemistry and Technology, Jožef Stefan Institute, Jamova 39, SI-1000 \\ Ljubljana, Slovenia \\ ${ }^{\S}$ Department of Chemistry, Nanoscience Center, Univeristy of Jyväskylä, P.O. Box 35, FI-40014 \\ Jyväskylä, Finland
}

\footnotetext{
* Corresponding author. Department of Inorganic Chemistry and Technology, Jožef Stefan Institute, Jamova 39, 1000 Ljubljana, Slovenia.Tel.: +386 147736 45; e-mail: evgeny.goreshnik@ijs.si
} 


\section{Abstract}

Using the alternating-current electrochemical technique, four new $\pi$-complexes, namely $\left[\mathrm{Cu}_{2}\left(\mathrm{C}_{11} \mathrm{H}_{10} \mathrm{~N}_{2} \mathrm{OS}\right)_{2} \mathrm{Br}_{1.91} \mathrm{Cl}_{0.09}\right]$ (1), $\left[\mathrm{Cu}\left(\mathrm{C}_{11} \mathrm{H}_{10} \mathrm{~N}_{2} \mathrm{OS}\right) \mathrm{NO}_{3}\right]$ (2), $\left[\mathrm{Cu}_{2}\left(\mathrm{C}_{11} \mathrm{H}_{10} \mathrm{~N}_{2} \mathrm{OS}\right)_{2}\left(\mathrm{H}_{2} \mathrm{O}\right)_{2}\right]\left(\mathrm{BF}_{4}\right)_{2}$ (3) and $\left[\mathrm{Cu}_{2}\left(\mathrm{C}_{11} \mathrm{H}_{10} \mathrm{~N}_{2} \mathrm{OS}\right)_{2}\left(\mathrm{H}_{2} \mathrm{O}\right)_{2}\right]\left(\mathrm{ClO}_{4}\right)_{2}$ (4), were obtained using copper(II) salts and the 2(allylthio)-5-phenyl-1,3,4-oxadiazole $\left(\mathrm{C}_{11} \mathrm{H}_{10} \mathrm{~N}_{2} \mathrm{OS}\right)$ ligand. The metal and halogen centers in $\mathbf{1}$ form $\mathrm{Cu}_{2} \mathrm{X}_{2}$ dimers; the $\mathrm{N}$-atom from the oxadiazole ring and the $\mathrm{C}=\mathrm{C}$ bond of the allyl group from the same ligand complete the copper coordination environment, giving $\left[\mathrm{Cu}\left(\mathrm{C}_{11} \mathrm{H}_{10} \mathrm{~N}_{2} \mathrm{OS}\right) \mathrm{X}\right]_{2}$ isolated fragments. The ligand plays the same chelating role in $\mathbf{2}$, whereas the $\mathrm{O}\left(\mathrm{NO}_{3}\right)$ atom occupies the third position in the copper atom's equatorial plane. Two more elongated $\mathrm{Cu}-\mathrm{O}\left(\mathrm{NO}_{3}\right)$ contacts associate the $\mathrm{Cu}\left(\mathrm{C}_{11} \mathrm{H}_{10} \mathrm{~N}_{2} \mathrm{OS}\right) \mathrm{NO}_{3}$ fragments into $1 \mathrm{D}$ chains. The geometries of the $\left[\mathrm{Cu}\left(\mathrm{C}_{11} \mathrm{H}_{10} \mathrm{~N}_{2} \mathrm{OS}\right)\right]_{2}{ }^{2+}$ cationic units in $\mathbf{3}$ and $\mathbf{4}$ are affected by the position of two water molecules in the coordination spheres of the copper atoms with respect to the plane containing the oxadiazole rings and the copper atoms. The molecular structures and Raman spectra of the compounds were computed using the DFT/B3LYP/cc-pVDZ level of theory. The results are compared with the experimental data obtained and used for vibrational band assignment.

Keywords: copper(I); olefin; $\pi$-complex; 1,3,4-oxadiazole derivatives; crystal structure; $a c$ electrochemical technique, DFT, Raman spectroscopy 


\section{Introduction}

Complexes involving transition metals and olefins have received considerable theoretical and practical interest because of remarkable advances in the development of various catalytic processes. This means they have also played an important role in organometallic chemistry in recent decades [1-4]. Among them, considerable attention has been paid to the investigation of $\mathrm{Cu}(\mathrm{I}) \pi$ complexes with allyl derivatives of heterocyclic organic compounds, since the combination of the allyl radical and heterocyclic cores (both of which, according to hard soft acid base (HSAB) theory, act as soft bases) efficiently contributes to the stabilization of inorganic fragments that occur only extremely rarely [5]. This is caused by a certain deficiency in the electron density in the $d_{x 2-y 2}$ orbital (due to the $\pi$-dative $(\mathrm{Cu} \rightarrow \mathrm{C}=\mathrm{C})_{\pi}$ component of the $\mathrm{Cu}(\mathrm{I})$-olefin bond) and the difference in electron donation from the atoms of the competing heterocylic molecule and the present inorganic (or organic) anions. For example, despite the "hard character" of the $\mathrm{SiF}_{6}{ }^{2-}$ anion, its fluorine atoms in the presence of $\pi, \sigma$-coordinated 1-allylbenzotriazole were first observed to be bound with a "soft" $\mathrm{Cu}(\mathrm{I})$ center in the corresponding crystalline compound [6]. A specific contribution of the allyl radical attached to the 2-amino-5-phenyl-1,3,4-thiadiazole fragment through an amino group was also observed in an acetonitrile solution, where the organic ligand, while reacting with $\mathrm{CuNO}_{3}$, undergoes deprotonation and gives a new, tetra-nuclear $\left[\mathrm{Cu}^{\mathrm{I}}(\mathrm{L})\right]_{4}(\mathrm{~L}=$ ligand $)$ complex of the azanide type [7].

Among a number of nitrogen-containing, five-membered aromatic heterocycles with an electron-deficient nature, 1,3,4-oxadiazole derivatives have been intensively studied in the fields of organic light-emitting diodes, biological activity, as well as crystal engineering [8-11]. Despite the huge advances in the synthesis and the possible applications of 1,3,4-oxadiazole derivatives, the data concerning their use as co-ligands in metal-olefine $\pi$-coordination is still limited: only 16 corresponding entries have been found in the Cambridge Crystallographic Database (CCD) [12], while the analogous $\mathrm{Cu}(\mathrm{I}) \pi$-compounds appear to be structurally unstudied. Moreover, the coordination of $\mathrm{CuCl}, \mathrm{CuNO}_{3}$ and $\mathrm{CuClO}_{4}$ with a 1,3,4-oxadiazole core has not been observed in the CCD references. To reveal the main features of copper-olefin $\pi$-coordination in the presence of a 1,3,4-oxadiazole core we present the synthesis and structural characterization of four new $\pi$ complexes, $\left[\mathrm{Cu}_{2}(\text { Atphod })_{2} \mathrm{Br}_{1.91} \mathrm{Cl}_{0.09}\right]$ (1), $\left[\mathrm{Cu}(\right.$ Atphod $\left.) \mathrm{NO}_{3}\right](\mathbf{2}),\left[\mathrm{Cu}_{2}(\text { Atphod })_{2}\left(\mathrm{H}_{2} \mathrm{O}\right)_{2}\right]\left(\mathrm{BF}_{4}\right)_{2}(\mathbf{3})$ and $\left[\mathrm{Cu}_{2}(\text { Atphod })_{2}\left(\mathrm{H}_{2} \mathrm{O}\right)_{2}\right]\left(\mathrm{ClO}_{4}\right)_{2}$ (4), with 2-(allylthio)-5-phenyl-1,3,4-oxadiazole (Atphod), emphasizing the influence of the inorganic anions on the diverse $1,3,4$-oxadiazole $\pi, \sigma$-coordination mode with the $\mathrm{Cu}^{+}$ion, in particular enabling the first observation of $\mathrm{CuNO}_{3}$ and $\mathrm{CuClO}_{4}$ binding with a 1,3,4-oxadiazole ring. The compounds were studied by means of single-crystal XRD and Raman spectroscopy. 


\section{Experimental}

\subsection{Materials and instrumentation}

Unless mentioned otherwise, all the chemicals were obtained from commercial sources and used without further purification. The NMR experiments, i.e. ${ }^{1} \mathrm{H}$ NMR $(500 \mathrm{MHz})$ and ${ }^{13} \mathrm{C}\left[{ }^{1} \mathrm{H}\right]$ NMR (125 MHz), were recorded on a Bruker Advance 500-MHz NMR spectrometer. The chemical shifts are reported in ppm relative to the residual peak of deuterated $\mathrm{CDCl}_{3}$ for the ${ }^{1} \mathrm{H}$ and ${ }^{13} \mathrm{C}\left[{ }^{1} \mathrm{H}\right]$ NMR spectra. Diffraction data were collected on an Agilent Gemini A four-circle diffractometer equipped with an Atlas CCD detector.

\subsection{Preparation of 2-(allylthio)-5-phenyl-1,3,4-oxadiazole (Atphod)}

5-Phenyl-1,3,4-oxadiazole-2-thiol was synthesized from benzhydrazide and carbon disulfide, in accordance with the reported method [13]. The reaction of 5-phenyl-1,3,4-oxadiazole-2-thiol with 3-chloroprop-1-ene in the presence of $\mathrm{KOH}$ yields the corresponding 2-(prop-2-en-1-ylsulfanyl)-5phenyl-1,3,4-oxadiazole (Atphod) as a yellow liquid (at room temperature). The yield was about 93\%. Atphod: ${ }^{1} \mathrm{H}$ NMR (500 MHz, $\mathrm{CDCl}_{3}$ ) $\delta$, ppm: 7.91 (dd, $\left.J=6.3,1.3 \mathrm{~Hz}, 2 \mathrm{H}, \mathrm{H}_{\mathrm{Ph}}-2,6\right), 7.49-$ $7.33\left(\mathrm{~m}, 3 \mathrm{H}, \mathrm{H}_{\mathrm{Ph}}-3-5\right), 6.04-5.83(\mathrm{~m}, 1 \mathrm{H},=\mathrm{CH}), 5.33\left(\mathrm{dd}, J=16.9,1.2 \mathrm{~Hz}, 1 \mathrm{H}, \mathrm{CH}_{2}=\right), 5.15(\mathrm{dd}, J=$ 10.0, $\left.0.8 \mathrm{~Hz}, 1 \mathrm{H}, \mathrm{CH}_{2}=\right), 3.85\left(\mathrm{~d}, J=7.0 \mathrm{~Hz}, 2 \mathrm{H}, \mathrm{CH}_{2}\right) .{ }^{13} \mathrm{C} \mathrm{NMR}\left(126 \mathrm{MHz}, \mathrm{CDCl}_{3}\right) \delta$, ppm: 165.69 (C-h-ring), 163.53 (C-h-ring), 131.58 (=CH), 128.91 (C-Ph), 126.48 (C-Ph), 123.46 (C-Ph), $119.62\left(\mathrm{CH}_{2}=\right), 35.11\left(\mathrm{CH}_{2}\right)$.

\subsection{Synthesis of the copper(I) $\pi$-complexes}

Crystals of the complexes were obtained under the conditions of alternating-current electrochemical synthesis [5,7,14-21], starting from an alcohol solution of the Atphod ligand and the corresponding copper(II) salt.

\subsubsection{Preparation of $\left[\mathrm{Cu}_{2}(\operatorname{Atphod})_{2} \mathrm{Br}_{1.91} \mathrm{Cl}_{0.09}\right](1)$}

To $4.3 \mathrm{~mL}$ of an ethanol solution of $\mathrm{CuBr}_{2}(1.1 \mathrm{mmol}, 0.246 \mathrm{~g}), 0.218 \mathrm{~g}$ (1.0 mmol) of Atphod and $0.034 \mathrm{~g}(0.2 \mathrm{mmol})$ of $\mathrm{NaCl}$ were added. The mixture was carefully stirred, the resulting solution was placed into a $5 \mathrm{~mL}$ test tube and then copper-wire electrodes in cork were inserted. With the application of an alternating-current tension (frequency $50 \mathrm{~Hz}$ ) of $0.55 \mathrm{~V}$ for 3 days the solution was discolored and good-quality colorless crystals of $\mathbf{1}$ appeared on the copper electrodes. The yield was about $20 \%$. M.p.: $156^{\circ} \mathrm{C}$.

\subsubsection{Preparation of $\left[\mathrm{Cu}(\right.$ Atphod $\left.) \mathrm{NO}_{3}\right](2)$}


To $4.3 \mathrm{~mL}$ of an ethanol solution of $\mathrm{Cu}\left(\mathrm{NO}_{3}\right)_{2} \cdot 3 \mathrm{H}_{2} \mathrm{O}(1.2 \mathrm{mmol}, 0.290 \mathrm{~g}), 0.218 \mathrm{~g}(1.0 \mathrm{mmol})$ of Atphod was added. The resulting green-colored mixture, after careful stirring, was subjected to an alternating-current tension (frequency $50 \mathrm{~Hz}$ ) of $0.60 \mathrm{~V}$ for 2 days. Good-quality colorless crystals of 2 appeared on the copper electrodes. The yield was about $20 \%$. M.p.: $137^{\circ} \mathrm{C}$.

\subsubsection{Preparation of $\left[\mathrm{Cu}_{2}(\text { Atphod })_{2}\left(\mathrm{H}_{2} \mathrm{O}\right)_{2}\right]\left(\mathrm{BF}_{4}\right)_{2}(3)$}

To $4.3 \mathrm{~mL}$ of an ethanol solution of $\mathrm{Cu}\left(\mathrm{BF}_{4}\right)_{2} \cdot 6 \mathrm{H}_{2} \mathrm{O}(1.1 \mathrm{mmol}, 0.380 \mathrm{~g}), 0.218 \mathrm{~g}(1.0 \mathrm{mmol})$ of Atphod was added. With the application of an alternating-current tension (frequency $50 \mathrm{~Hz}$ ) of 0.6 $\mathrm{V}$ for 1 day, crystals of 3 appeared on the copper electrodes. The yield was about 15\%. M.p.: $173{ }^{\circ} \mathrm{C}$ (dec.).

\subsubsection{Preparation of $\left[\mathrm{Cu}_{2}(\text { Atphod })_{2}\left(\mathrm{H}_{2} \mathrm{O}\right)_{2}\right]\left(\mathrm{ClO}_{4}\right)_{2}(4)$}

To $4.3 \mathrm{~mL}$ of an ethanol solution of $\mathrm{Cu}\left(\mathrm{ClO}_{4}\right)_{2} \cdot 6 \mathrm{H}_{2} \mathrm{O}(1.1 \mathrm{mmol}, 0.408 \mathrm{~g}), 0.218 \mathrm{~g}$ (1.0 mmol) of Atphod was added. With the application of an alternating-current tension (frequency $50 \mathrm{~Hz}$ ) of 0.6 $\mathrm{V}$ for 2 days, the green solution was discolored and good-quality colorless crystals of $\mathbf{4}$ appeared on the copper electrodes. The yield was about $15 \%$, M.p.: $165^{\circ} \mathrm{C}$.

\subsection{Single crystal $X$-ray diffraction studies.}

Single-crystal data were collected on a Gemini A diffractometer equipped with an Atlas CCD detector, using graphite monochromated $\mathrm{CuKa}$ radiation for crystals $\mathbf{1}$ and $\mathbf{2}$ or graphite monochromated MoKa radiation for compounds 3 and $\mathbf{4}$. The collected diffraction data for 1-4 were processed with the CrysAlis PRO program [22]. The structures were solved using direct methods with SHELXS-97 and refined using the least-squares method on $F^{2}$ with SHELXL-2013 and using the graphical interface of OLEX2 [23-25]. The atomic displacements for the nonhydrogen atoms were refined using an anisotropic model. The hydrogen atoms (except the water molecules) were placed in ideal positions and refined as riding atoms with relative isotropic displacement parameters. In $\mathbf{2}$ and $\mathbf{3}$, the one allylsulfanyl group (C3 and C4 atoms) is disordered over two sites with an occupancy ratio of 0.886(6):0.114(6) and 0.874(4):0.126(4) respectively. Similar behaviour of the allylsulfanyl group was observed in 4. Also, the $\mathrm{ClO}_{4}{ }^{-}$anion $(\mathrm{O} 3, \mathrm{O} 4$ and O6 atoms) is disordered in 4 over two sites with an occupancy ratio of 0.798(6):0.202(6). The crystal parameters, data collection and the refinement are summarized in Table 1. 
Table 1. Selected crystal data and structure refinement parameters of $\mathbf{1 - 4} .^{\text {[a] }}$

\begin{tabular}{|c|c|c|c|c|}
\hline Crystal data & 1 & 2 & 3 & 4 \\
\hline $\begin{array}{l}\text { CCDC number } \\
\text { (Appendix A) }\end{array}$ & 1531990 & 1531991 & 1531992 & 1531993 \\
\hline Empirical formula & $\mathrm{C}_{22} \mathrm{H}_{20} \mathrm{Br}_{1.91} \mathrm{Cl}_{0.09} \mathrm{Cu}_{2} \mathrm{~N}_{4} \mathrm{O}_{2} \mathrm{~S}_{2}$ & $\mathrm{C}_{11} \mathrm{H}_{10} \mathrm{CuN}_{3} \mathrm{O}_{4} \mathrm{~S}$ & $\mathrm{C}_{22} \mathrm{H}_{24} \mathrm{Cu}_{2} \mathrm{~N}_{4} \mathrm{O}_{4} \mathrm{~S}_{2} \mathrm{~B}_{2} \mathrm{~F}_{8}$ & $\mathrm{C}_{22} \mathrm{H}_{24} \mathrm{Cu}_{2} \mathrm{~N}_{4} \mathrm{O}_{12} \mathrm{~S}_{2} \mathrm{Cl}_{2}$ \\
\hline F. w. $\left(\mathrm{g} \mathrm{mol}^{-1}\right)$ & 719.35 & 343.82 & 773.27 & 798.55 \\
\hline Crystal system, & Triclinic, & Monoclinic, & Monoclinic, & Monoclinic, \\
\hline$a(\AA)$ & $7.737(2)$ & $23.6143(9)$ & $10.7140(5)$ & $10.2776(3)$ \\
\hline$b(\AA)$ & $8.470(3)$ & $7.5312(4)$ & $8.1394(4)$ & $10.5321(3)$ \\
\hline$c(\AA)$ & $10.182(7)$ & $15.9270(8)$ & $33.3579(14)$ & $13.4213(4)$ \\
\hline$\alpha\left(^{\circ}\right)$ & $96.87(4)$ & - & - & \\
\hline$\beta\left(^{\circ}\right)$ & $94.43(4)$ & $113.493(4)$ & $91.771(4)$ & $98.415(3)$ \\
\hline$\gamma\left({ }^{\circ}\right)$ & $110.63(3)$ & - & - & - \\
\hline$V\left(\AA^{3}\right)$ & $614.9(5)$ & $2597.7(2)$ & $2907.6(2)$ & $1437.14(7)$ \\
\hline$Z$ & 1 & 8 & 4 & 2 \\
\hline$\mu\left(\mathrm{mm}^{-1}\right)$ & 7.687 & 4.056 & 1.695 & 1.881 \\
\hline$F(000)$ & 354.3 & 1392 & 1552 & 808 \\
\hline Crystal size (mm) & $0.41 \times 0.18 \times 0.10$ & $\begin{array}{l}0.21 \times 0.20 \times \\
0.15\end{array}$ & $0.37 \times 0.30 \times 0.06$ & $0.55 \times 0.27 \times 0.07$ \\
\hline Crystal color & colorless & colorless & colorless & colorless \\
\hline $\begin{array}{l}\text { Calculated density, } \\
\left(\mathrm{g} / \mathrm{cm}^{3}\right)\end{array}$ & 1.943 & 1.758 & 1.766 & 1.845 \\
\hline \multicolumn{5}{|l|}{ Data collection } \\
\hline $\begin{array}{l}\text { Radiation type, } \\
\text { wavelength, } \lambda(\AA)\end{array}$ & $\mathrm{Cu} \mathrm{Ka}, 1.5418$ & $\mathrm{Cu} \mathrm{Ka}, 1.5418$ & Мо $K a, 0.71073$ & Мо $K a, 0.71073$ \\
\hline Temperature $(K)$ & $150(2)$ & $150(2)$ & $150(2)$ & $150(2)$ \\
\hline$R\left[F^{2}>2 \sigma\left(F^{2}\right)\right]$ & 0.034 & 0.050 & 0.033 & 0.032 \\
\hline$w R\left(F^{2}\right)$ & 0.093 & 0.141 & 0.079 & 0.080 \\
\hline $\mathrm{GooF}=S$ & 1.040 & 1.043 & 1.067 & 1.052 \\
\hline
\end{tabular}

\subsection{Raman spectroscopy}

Raman spectra were measured in the air on crystals of 1-4 and the ligand powder with a Horiba Jobin-Yvon LabRAM HR spectrometer using the 632.81-nm excitation line of a He-Ne laser with a power of $17 \mathrm{~mW}$. The spectrometer was calibrated using a Si polycrystalline plate as a standard with a characteristic band at $520.6 \mathrm{~cm}^{-1}$.

\subsection{Computational details}

All the calculations were performed at the DFT/B3LYP/cc-PVDZ level [26,27] using the GAMESS(US) program package [28]. A basis set with effective core potentials (ECPs) was applied for the copper atoms. The initial geometries, derived from the crystal structure, were assumed to have $C_{1}$ symmetry and were utilized for the geometry optimization. The equilibrium geometries obtained were used for the Forces Constants matrix calculation. A polarizability tensor was then calculated and the resulting Raman activities $\left(S_{i}\right)$ were converted to Raman intensities $\left(I_{i}\right)$ using the following relationship from the intensity theory of Raman scattering [29,30]. 


\section{Results and discussion}

\subsection{Crystal structures.}

The structures 1-4 demonstrate the first examples of copper(I)-olefin $\pi$-complexes with an active 1,3,4-oxadiazole core bonded to $\mathrm{Cu}(\mathrm{I})$ ion. The atphod molecule in compounds $\mathbf{1}$ and $\mathbf{2}$ acts as a bidentate chelating $\pi, \sigma$-ligand, being attached to the $\mathrm{Cu}(\mathrm{I})$ ion by means of the $\mathrm{C}=\mathrm{C}$ bond of the allyl group and one the most nucleophilic N1 atoms of the oxadiazole ring (Figs. 1 and 2). The copper(I) atom in $\mathbf{1}$ adopts close to a trigonal pyramidal geometry $\left(\tau_{4}=0.85, \tau_{4}\right.$ - four-coordinate geometry index), including the $\mathrm{N}$ atom, the $\mathrm{C}=\mathrm{C}$ bond and one of the halogen $\mathrm{X}$ atoms in the basal plane of the metal polyhedron. The second halogen atom, that is apically bonded to the $\mathrm{Cu}(\mathrm{I})$ ion, is at a distance of 2.836(2) $\AA$ from the metal center, which is significantly shorter than the sum of the VdW radii of the $\mathrm{Cu}$ and $\mathrm{Cl}(3.15 \AA)$ or the $\mathrm{Cu}$ and $\mathrm{Br}(3.23 \AA)$ atoms, reported by Bondi, [31,32] and very much shorter than the corresponding sum of $4.20 \AA$ for the $\mathrm{Cu}$ and $\mathrm{Cl}$ atoms, recently discovered by Alvarez [33]. As a result, in $\mathbf{1}$ the bridging halogen atoms connect the organometallic $[\mathrm{Cu}($ Atphod $)]$ fragments into a centrosymmetric $\left[\mathrm{Cu}_{2}(\text { Atphod })_{2} \mathrm{Br}_{1.91} \mathrm{Cl}_{0.09}\right]$ dimer. A similar [$\left.\mathrm{N},(\mathrm{C}=\mathrm{C}) \mathrm{Cl}_{2}-\right]_{2}$ coordination topology for $\mathrm{CuX}(\mathrm{X}=\mathrm{Cl}$ or $\mathrm{Br})$ was previously found in the structure of seven copper(I) chloride and three copper(I) bromide complexes with olefin-containing ligands, among which are diallylamine [34], 1-allyl-3,5-dimethylpyrazole [35], (dimethyl(vinyl)silyl)pyridine [36], allylacetone oxime [37], and 2-(allylthio)benzimidazole [15].

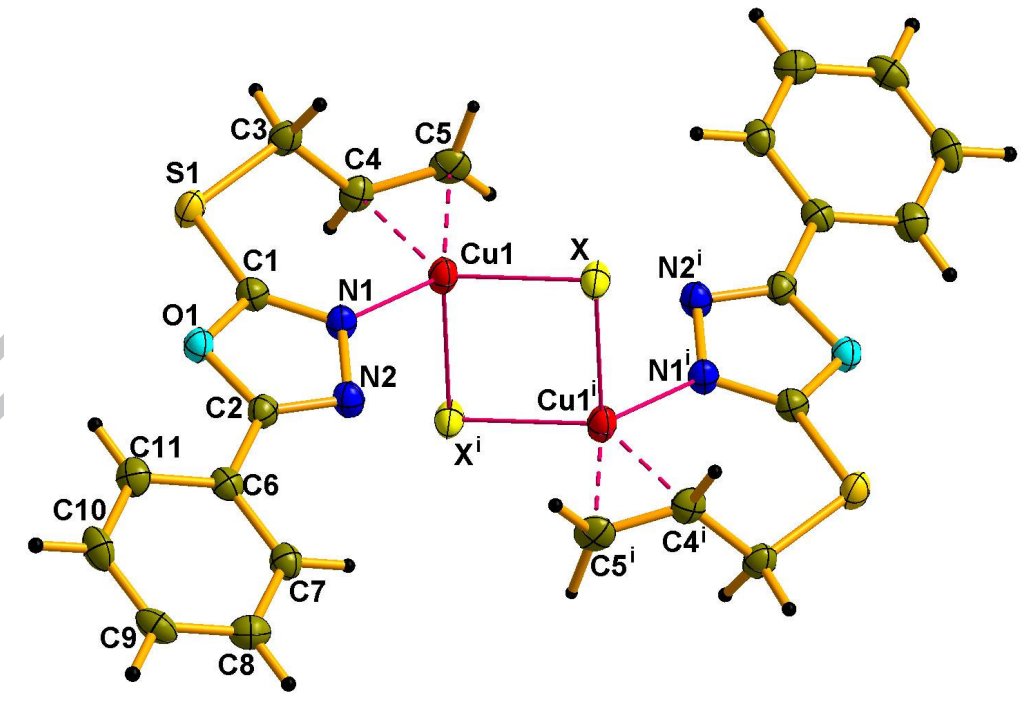

Figure 1. Fragment of the crystal structure of $\mathbf{1}$. Thermal ellipsoids are shown at $50 \%$ probability. Symmetry codes: (i) $1-x, 2-y, 2-z . \mathrm{X}=\mathrm{Br}, \mathrm{Cl}$. Selected bond length (in $\AA$ ) and angle (in deg) values: Cu1-X 2.3673(9), Cu1-X 2.836(2), Cu1-N1 1.986(3), Cu1-m 1.946(4) ( $m$ - middle point of C4=C5 bond), C4-C5 1.365(5), N1-N2 1.411(4), C2-C6 1.458(5), C1-N1 1.300(5), C2-N2 1.291(5), N1-Cu1-X 110.8(1), N1-Cu1-X 103.3(1), N1-Cu1-m 116.1(1), m-Cu1-X 124.7(1), m$\mathrm{Cu} 1-\mathrm{X}^{i}$ 91.0(1). 
A phenyl group of the Atphod ligand in complex 1 is tilted by $10.34^{\circ}$ with respect to the $1,3,4$ oxadiazole ring, and the distance of 1.458(5) $\AA$ for C2-C6 between the carbon atoms of the oxadiazole and phenyl rings indicates a significant contribution of the $\pi$-component to the bond. Due to the $\pi$-dative $\mathrm{Cu}(\mathrm{I}) \rightarrow(\mathrm{C}=\mathrm{C})_{\pi}$ part of the $\mathrm{Cu}(\mathrm{I})$-olefine interaction, the $\mathrm{C}=\mathrm{C}$ bond of the ligand allyl group in $\mathbf{1}$ is elongated to $1.365(5) \AA$, in comparison with the free $\mathrm{C}=\mathrm{C}$ distance in ethylene of

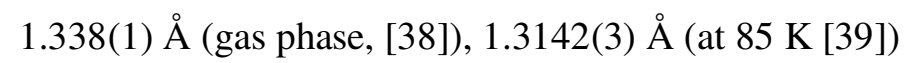

Taking into account that according to Pearson`s HSAB theory, a soft base, such as a $\mathrm{C}=\mathrm{C}$ bond, should readily react with a soft acid $\mathrm{Cu}(\mathrm{I})$ ion. The contributions of heterocyclic $\mathrm{N}$ atoms (possessing borderline basicity) to the metal coordination have a considerable effect on the $\mathrm{Cu}(\mathrm{I})$ ion's interaction with inorganic anions, thus stabilizing unknown (or less-stable), in the free state, copper(I) salts [5]. This conclusion is largely confirmed by the existence of the $\left[\mathrm{Cu}(\right.$ Atphod $\left.) \mathrm{NO}_{3}\right] \pi$ complex (2) in the crystalline form. To the best of our knowledge, $\mathbf{2}$ is the first known crystalline example of a $\mathrm{CuNO}_{3}$ compound containing a 1,3,4-oxadiazole ligand. Previously, the coordination behavior of 1,3,4-oxadiazole derivatives was studied exclusively with respect to copper(II) nitrate $[40,41]$.

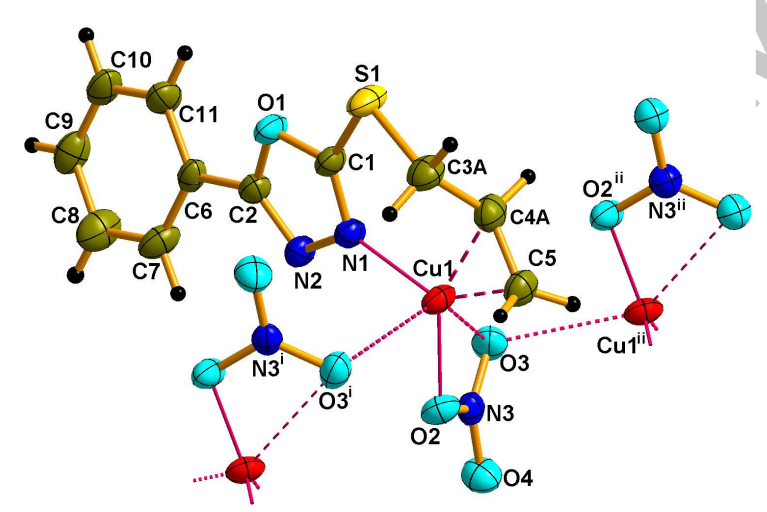

Figure 2. Fragment of the crystal structure 2. Thermal ellipsoids are shown at $50 \%$ probability. Symmetry codes: (i) $1.5-x, y-0.5,1.5-z$; (ii) $1.5-x, 0.5+y, 1.5-z$. Selected bond length (in $\AA$ ) and angle (in deg) values: Cu1-O2 1.990(2), Cu1-O3 ${ }^{i}$ 2.598(2), Cu1-N1 1.968(3), Cu1-m 1.910(4) ( $m$ - middle point of C4A=C5 bond), C4A-C5 1.383(5), N1-N2 1.411(4), C2-C6 1.458(5), C1-N1 1.292(4), C2-N2 1.289(4), N1-Cu1-O2 111.7(1), N1-Cu1-O3 ${ }^{i}$ 89.2(1), N1-Cu1-m 117.1(1), m$\mathrm{Cu} 1-\mathrm{O} 2$ 131.2(1), $m-\mathrm{Cu} 1-\mathrm{O}^{i}{ }^{9}$ 98.5(1), O3 ${ }^{i}-\mathrm{Cu} 1-\mathrm{O} 2^{i i}$ 167.3(1), O3 ${ }^{i}-\mathrm{Cu} 1-\mathrm{O} 3$ 129.7(1).

The $\mathrm{Cu}(\mathrm{I})$ atom in the structure of $\mathbf{2}$ adopts close to a trigonal-pyramidal geometry $\left(\tau_{4}=\right.$ 0.79) [42], with one oxadiazole $\mathrm{N}$ atom, the allylic $\mathrm{C}=\mathrm{C}$ bond and two $\mathrm{O}$ atoms of two symmetryrelated $\mathrm{NO}_{3}{ }^{-}$anions. The coordination of the apically bonded $\mathrm{O}^{i}$ atom is intriguing, since the $\mathrm{Cu}-$ $\mathrm{O}^{i}{ }^{i}$ distance value of $2.598(2) \AA$ is very close to the limiting distance of $2.63 \AA$ for a $\mathrm{Cu}-\mathrm{O}_{\text {ap }}$ 
interaction in the structures of $\mathrm{Cu}(\mathrm{I}) \pi$-complexes with allyl derivatives of heterocycles $[5,12]$. On the other hand, the fact that the copper atom is located in the plane of the equatorial ligands was never reported in the analogous compounds and indicates a significant deficiency of the electron density in the $d_{x 2-y 2}$ copper orbital due to an effective $\pi$-dative $\mathrm{Cu}(\mathrm{I}) \rightarrow(\mathrm{C}=\mathrm{C})_{\pi}$ component of the $\pi$ bond. The appearance of one more elongated $\mathrm{Cu}-\mathrm{O} 3$ contact with a distance of 2.729(2) $\AA$, shorter than the corresponding $\mathrm{r}_{\mathrm{vdW}} \operatorname{sum}(2.92 \AA)$, is mostly the result of geometrical factors, typically observed for a coordinated $\mathrm{NO}_{3}{ }^{-}$anion. It is worth noting that the $\mathrm{Cu}(\mathrm{I})$ anisotropic displacement parameter $U_{22}\left(0.0449(4) \AA^{2}\right)$, with a larger value than $U_{11}\left(0.0188(3) \AA^{2}\right)$ or $U_{33}\left(0.0278(3) \AA^{2}\right)$, indicates a greater metal anisotropy in two opposite directions, one of which is directed to the $\mathrm{O} 3^{i}$ atom and the other one to the $\mathrm{O}_{2}{ }^{i i}$ atom of another $\mathrm{NO}_{3}{ }^{-}$moiety $\left(\mathrm{Cu}-\mathrm{O} 2^{i i}\right) 3.469(3) \AA$. The above statement might suggest that the $\mathrm{Cu}$ atom in structure $\mathbf{2}$ is five-coordinated and adopts a geometry that occurs for the $\mathrm{Ag}(\mathrm{I})$ ion in its $\pi$-coordination with olefins [43,44]. Thus, bridging $\mathrm{NO}_{3}{ }^{-}$anions, by means of weak $\mathrm{Cu}-\mathrm{O}^{i}$ bonds in 2 , connect $[\mathrm{Cu}($ Atphod $)]$ units into infinite chains in the 010 direction.

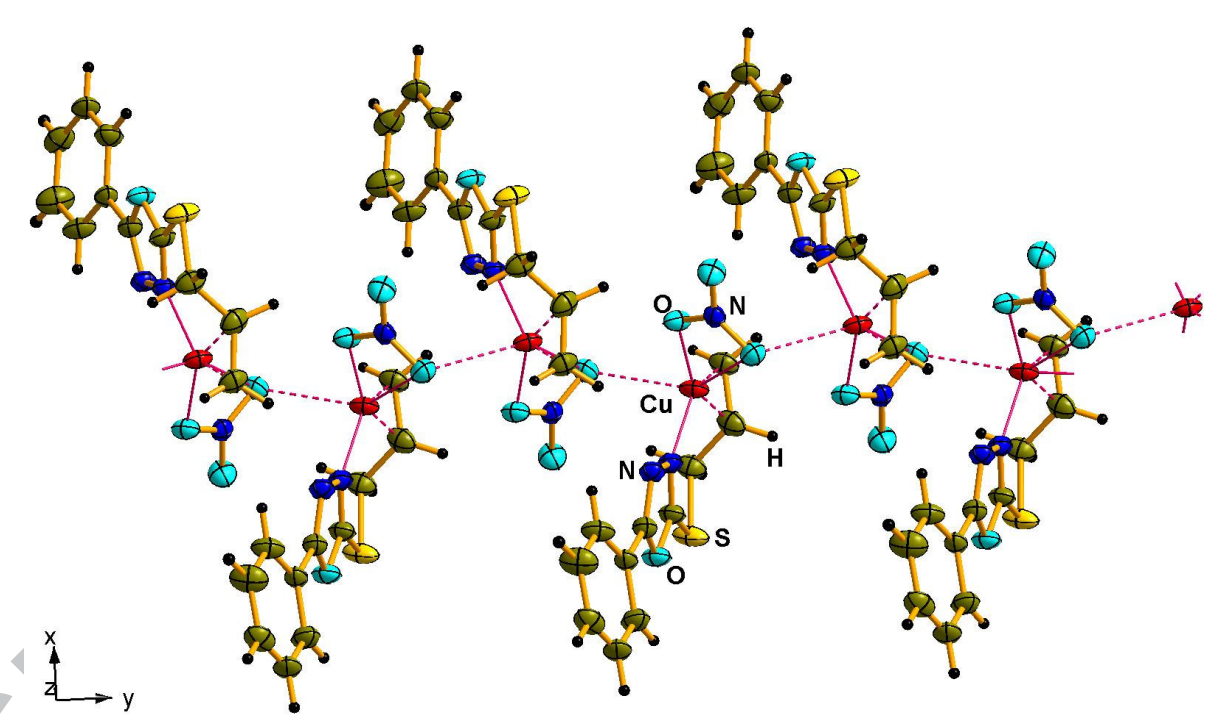

Figure 3. Coordination polymer in the structure of 2. Thermal ellipsoids are shown at $50 \%$ probability.

In contrast to $\mathbf{1}$ and $\mathbf{2}$, in complexes $\mathbf{3}$ and $\mathbf{4}$ the coordination behavior of the Atphod ligand, with regard to the $\mathrm{Cu}(\mathrm{I})$ ion, is reminiscent of 2-allylamino-5-methyl-1,3,4-thiadiazole [19] and 5allylthio-1-phenyl-tetrazoles [17, 45] in terms of dimer formation. The Atphod molecule in $\mathbf{3}$ and $\mathbf{4}$ acts as a tridentate chelate-bridging ligand, being attached to the metal centers by both oxadiazole $\mathrm{N}$ atoms (Figs. 4 and 5). A close to trigonal pyramidal $\mathrm{Cu}(\mathrm{I})$ environment in both structures (for $3 \tau 4=$ 0.83 and 0.85 ; for $4 \tau 4=0.80$ ) involves an allylic $\mathrm{C}=\mathrm{C}$ bond in an equatorial position and two different $\mathrm{N}$ atoms of two neighboring oxadiazole rings, while the apical position of the metal polyhedron is occupied by a water molecule. Thus, a pair of copper atoms connects two Atphod 
molecules into cationic $\left[\mathrm{Cu}_{2}(\text { Atphod })_{2}\right]^{2+}$ dimers, characterized in $\mathbf{3}$ and $\mathbf{4}$ by different symmetries and modes of coordination of the water molecules. A common tendency for the $\mathrm{BF}_{4}{ }^{-}$anion to be bound with a copper(I) center through a water bridge by means of hydrogen bonding leads to the appearance of the acentric $\left[\mathrm{Cu}_{2}(\text { Atphod })\left(\mathrm{H}_{2} \mathrm{O}\right)_{2}\right]^{2+}$ dimer, within which both $\mathrm{H}_{2} \mathrm{O}$ molecules are located on one side of the $\left[\mathrm{Cu}_{2}(\text { Atphod) })_{2}\right]^{2+}$ tecton (Fig. $4 a$ ). One of the $\mathrm{BF}_{4}{ }^{-}$anions in $\mathbf{3}$ is involved in an H-bridge between the water molecule of the same dimer, while the other one assembles the $\left[\left[\mathrm{Cu}_{2}(\text { Atphod })_{2}\left(\mathrm{H}_{2} \mathrm{O}\right)_{2}\right] \cdot \mathrm{BF}_{4}\right]$ synthons into an infinite chain (Fig. $5 a$ ). The dihedral angle between the 1,3,4-oxadiazole rings within the dimer is $20.9(1)^{\circ}$.

In contrast to $\mathbf{3}$, the structure of $\left[\mathrm{Cu}_{2}(\text { Atphod })_{2}\left(\mathrm{H}_{2} \mathrm{O}\right)_{2}\right]\left(\mathrm{ClO}_{4}\right)_{2}(4)$ is organized in another manner. Due to the aspiration of the $\mathrm{ClO}_{4}{ }^{-}$anion to form $\mathrm{O}-\mathrm{H} \cdots \mathrm{O}$ bonds in a more symmetrical array, the $\left[\mathrm{Cu}_{2}(\text { Atphod })\right]^{2+}$ tecton transforms into a centrosymmetrical dimer, allowing the $\mathrm{H}_{2} \mathrm{O}$ molecule to coordinate the $\mathrm{Cu}(\mathrm{I})$ ion from different sides of the $\left[\mathrm{Cu}_{2}(\text { Atphod })_{2}\right]^{2+}$ tecton. Thus, it provides an organization of $\left[\mathrm{Cu}_{2}(\text { Atphod })_{2}\left(\mathrm{H}_{2} \mathrm{O}\right)_{2}\right]^{2+}$ cations and $\mathrm{ClO}_{4}^{-}$anions into hydrogen-bonded $2 D$ layers (Fig. $5 b$ ). It should be noted that the $\mathrm{CuClO}_{4}$ coordination to the 1,3,4-oxadiazole ring was previously studied only for copper(II) salts $[40,46]$.

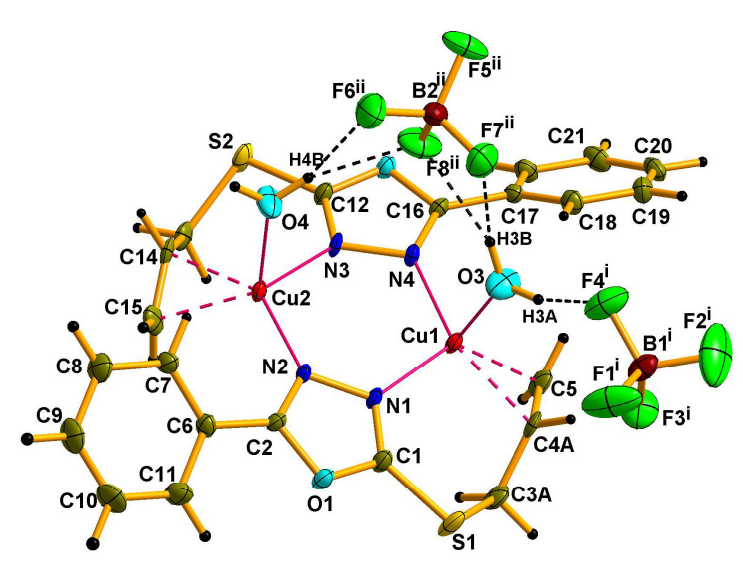

a

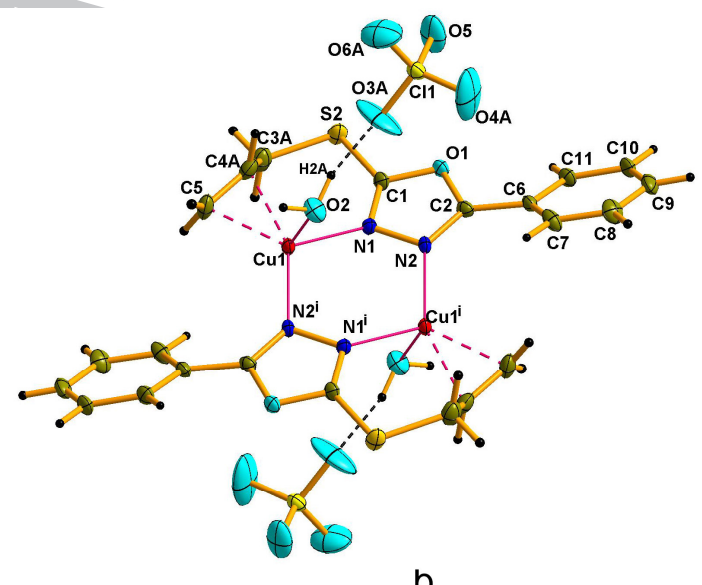

$\mathrm{b}$

Figure 4. Part of the structure of $\mathbf{3}(a)$ and centrosymmetric fragment of $\mathbf{4}(b)$. Thermal ellipsoids are shown at $50 \%$ probability. The disorders of the allyl group (attached to $\mathrm{Cu} 2$, in $\mathbf{3}$ ) and the $\mathrm{ClO}_{4}^{-}$ anion (in 4) are omitted for clarity. Selected bond length (in $\AA$ ) and angle (in deg) values: 3: Cu1N1 2.030(2), Cu1-N4 1.994(2), Cu1-O3 2.191(2), Cu2-N2 2.002(2), Cu2-N3 2.036(2), Cu2-O4 2.191(2), Cu1-m1 1.964(3), Cu2-m2 1.962(2) ( $m 1$ and $m 2-$ middle point of the $\mathrm{C} 4 \mathrm{~A}=\mathrm{C} 5$ and C14=C15 bonds), C4A-C5 1.359(4), C14-C15 1.354(3), N1-Cu1-O3 100.31(8), N4-Cu1-O3 96.11(8), N1-Cu1-ml 113.4(1), ml-Cu1-O3 100.1(1), ml-Cu1-N4 129.5(1), N2-Cu2-N3 109.76(7), N2-Cu2-O4 101.33(8), N2-Cu2-m2 127.0(1), m2-Cu2-O4 107.0(1), m2-Cu2-N3 113.2(1). Symmetry codes in 3: (i) -x, 2-y, 1-z; (ii) x, 1+y, z;

4: Cu1-N1 2.004(2), Cu1-N2 ${ }^{i}$ 1.992(2), Cu1-O2 2.310(2), Cu1-m 1.941(2) ( $m$ - middle point of te $\mathrm{C} 4=\mathrm{C} 5$ bond), C4A-C5 1.347(4), N1-N2 1.413(3), C2-C6 1.463(3), C1-N1 1.300(3), C2-N2 
1.294(3), N1-Cu1-O2 92.08(8), N1-Cu1-N2 ${ }^{i}$ 111.34(7), N2 ${ }^{i}-\mathrm{Cu} 1-\mathrm{O} 2$ 86.93(8), N1-Cu1-m 112.9(1), N2-Cu1-m 135.0(1), m-Cu1-O2 98.9(1). Symmetry code in 4: (i) 1-x, 1-y, -z.

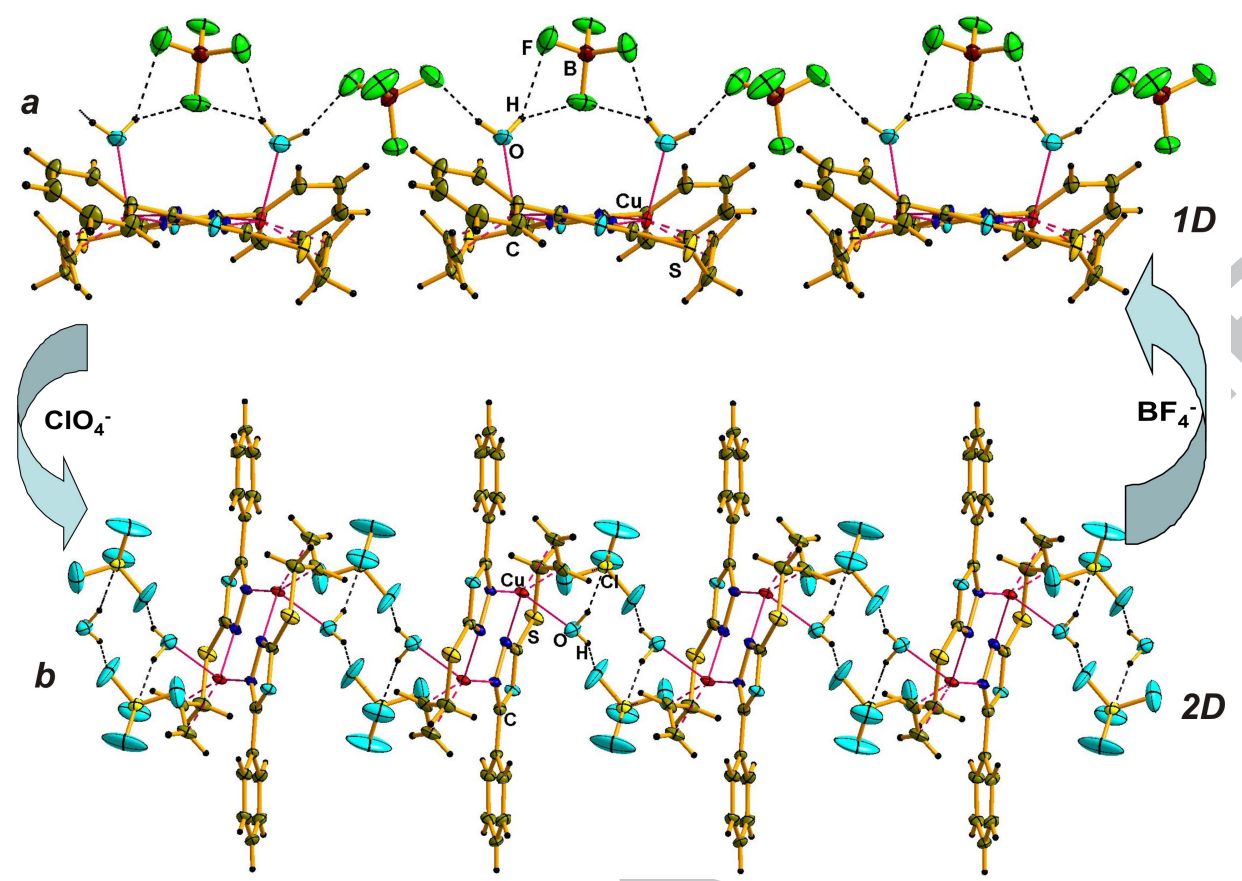

Figure 5. H-bonded arrays in the structures of $\mathbf{3}$ (a) and $\mathbf{4}$ (b). Thermal ellipsoids are shown at $50 \%$ probability.

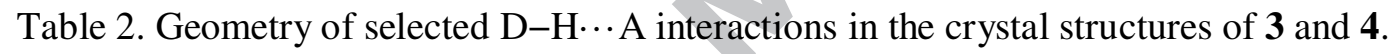

\begin{tabular}{|c|c|c|c|c|c|}
\hline Atoms involved & Symmetry & \multicolumn{3}{|c|}{ Distances, § } & Angle, deg \\
\hline D-H $\cdots \mathbf{A}$ & & $\mathbf{D} \cdots \mathbf{H}$ & $\mathbf{H} \cdots A$ & D $\cdots A$ & D-H $\cdots A$ \\
\hline \multicolumn{6}{|c|}{3} \\
\hline $\mathrm{O} 3-\mathrm{H} 3 \mathrm{~B} \cdots \mathrm{F} 7$ & & $0.75(2)$ & $2.23(2)$ & $2.890(3)$ & $148(3)$ \\
\hline $\mathrm{O} 3-\mathrm{H} 3 \mathrm{~B} \cdots \mathrm{F} 8$ & $\mathrm{x}, 1+\mathrm{y}, \mathrm{z}$ & $0.75(2)$ & $2.34(2)$ & $3.011(3)$ & $150(3)$ \\
\hline $\mathrm{O} 3-\mathrm{H} 3 \mathrm{~A} \cdots \mathrm{F} 4$ & $-x, 2-y, 1-z$ & $0.75(2)$ & $2.04(2)$ & $2.779(3)$ & $172(3)$ \\
\hline O4-H4B $\cdots$ F6 & $\mathrm{x}, 1+\mathrm{y}, \mathrm{z}$ & $0.74(2)$ & $2.42(2)$ & $3.052(3)$ & $143(3)$ \\
\hline $\mathrm{O} 4-\mathrm{H} 4 \mathrm{~B} \cdots \mathrm{F} 8$ & $\mathrm{x}, 1+\mathrm{y}, \mathrm{z}$ & $0.74(2)$ & $2.28(2)$ & $2.977(3)$ & $157(3)$ \\
\hline $\mathrm{O} 4-\mathrm{H} 4 \mathrm{~A} \cdots \mathrm{F} 2$ & $1-x, 2-y, 1-z$ & $0.75(2)$ & $2.06(2)$ & $2.803(3)$ & $175(4)$ \\
\hline \multicolumn{6}{|l|}{ 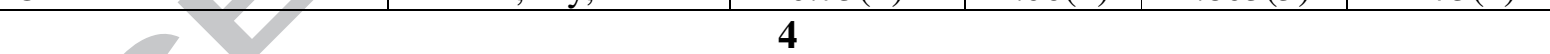 } \\
\hline $\mathrm{O} 2-\mathrm{H} 2 \mathrm{~A} \cdots \mathrm{O} 3 \mathrm{~A}$ & & $0.85(4)$ & $1.92(4)$ & $2.692(4)$ & 151(3) \\
\hline $\mathrm{O} 2-\mathrm{H} 2 \mathrm{~B} \cdots \mathrm{O} 5$ & $1.5-x, 0.5+y, 0.5-z$ & $0.84(4)$ & $2.04(4)$ & $2.847(3)$ & $160(4)$ \\
\hline
\end{tabular}

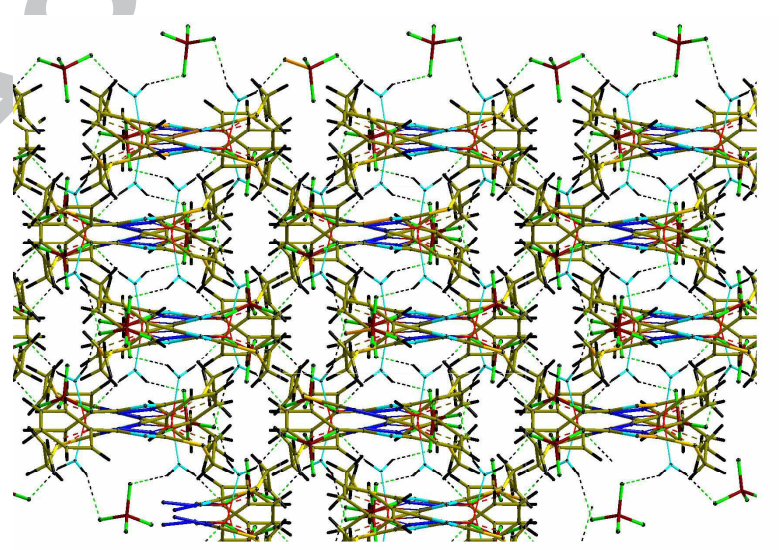

a

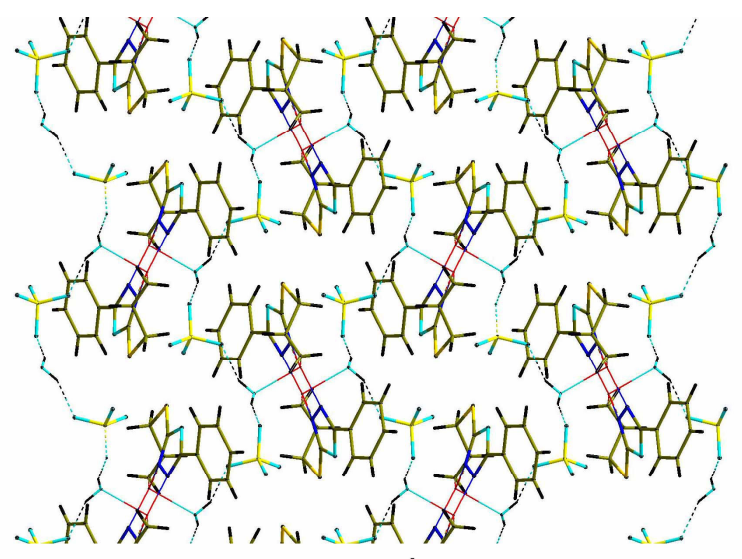

b 
Figure 6. Packing mode of $\mathbf{3}(a)$ and $\mathbf{4}(b)$ along the [100] direction. A plain stick model is used for clarity.

\subsection{Computed geometries}

The optimized structures are shown in Figures S1-S3, Supplementary Material. Selected geometrical parameters for every compound in comparison to the experimental ones are provided below each figure.

All the compounds were computed with $C_{1}$ symmetry. For compound 1 both halogen atoms were set to be $\mathrm{Br}$, since the fraction of $C_{1}$ is low in the experimental structure. The geometrical parameters at the equilibrium point appeared to be close to the experimental values.

For compound 2 the calculation was on an anion with two $\mathrm{NO}_{3}{ }^{-}$groups to keep the coordination surrounding the $\mathrm{Cu}$ atom. As expected, a slight distortion of the $\mathrm{NO}_{3}^{-}$group's position appeared due to the absence of lattice influence, i.e., the $\mathrm{O} 3$ atom is pushed back and the $\mathrm{Cu}$ atom has only two oxygen atoms within the coordination sphere. This change affected the $\mathrm{Cu}-\mathrm{O}$ distances, and the $\mathrm{Cu}-\mathrm{O} 3^{i}$ bond at the equilibrium point has a length of $2.0539 \AA$, while the same bond in the experimental structure was significantly longer at 2.598(2) $\AA$.

For compounds $\mathbf{3}$ and $\mathbf{4}$ the geometry optimization faced some difficulties: in both cases the oxygen atom from the water molecules in the coordination sphere of the $\mathrm{Cu}$ atom tends to be equidistant from both metal centers. This leads to the exclusion of a second water molecule in the case of compound 3, so it was decided to use the dimer structure without water molecules. The optimized geometry appeared to be close to the experimental geometry. All the optimized structures are available in the Supplementary Material in XYZ format.

The equilibrium geometries were applied for Raman spectra calculations. In the computed spectra no imaginary frequencies appeared.

\subsection{Raman spectra}

The Raman spectra of compounds 1-4 are shown in Figure 7. The band assignments were made on the basis of the computed Raman spectra, see Tables S1-S3. The spectrum of the pure ligand is given in Figure S4.

The most intensive band in all the spectra appeared at $1604-1610 \mathrm{~cm}^{-1}$ and is due to $v(\mathrm{CC})$ from the ring of the Atphod ligand. The most interesting peculiarity of the spectra is related to the bands from the allyl group. The $v(\mathrm{C}=\mathrm{C})$ band from the allyl group is a commonly used "fingerprint" for such compounds; it appeared at $1639 \mathrm{~cm}^{-1}$ in the spectrum of the pure ligand and was observed in the spectra of compounds 1-4 at 1561, 1565, 1562 and $1566 \mathrm{~cm}^{-1}$, respectively. The computed spectrum for the cationic unit $\left[\mathrm{Cu}_{2}(\text { Atphod })_{2}\right]^{2+}$ appearing in the structures of $\mathbf{3}$ and $\mathbf{4}$ indicated that this band is of zero intensity and is expected to appear at approximately $1570 \mathrm{~cm}^{-1}$. Presumably, the 
suppression of the $v(\mathrm{C}=\mathrm{C})_{\text {allyl }}$ band is caused by the contribution of the $\mathrm{Cu}$ coordination surroundings to the resulting polarizability tensor, whereas the presence of water molecules in the structures of $\mathbf{3}$ and $\mathbf{4}$ indicated distortions, so that the band becomes Raman active.

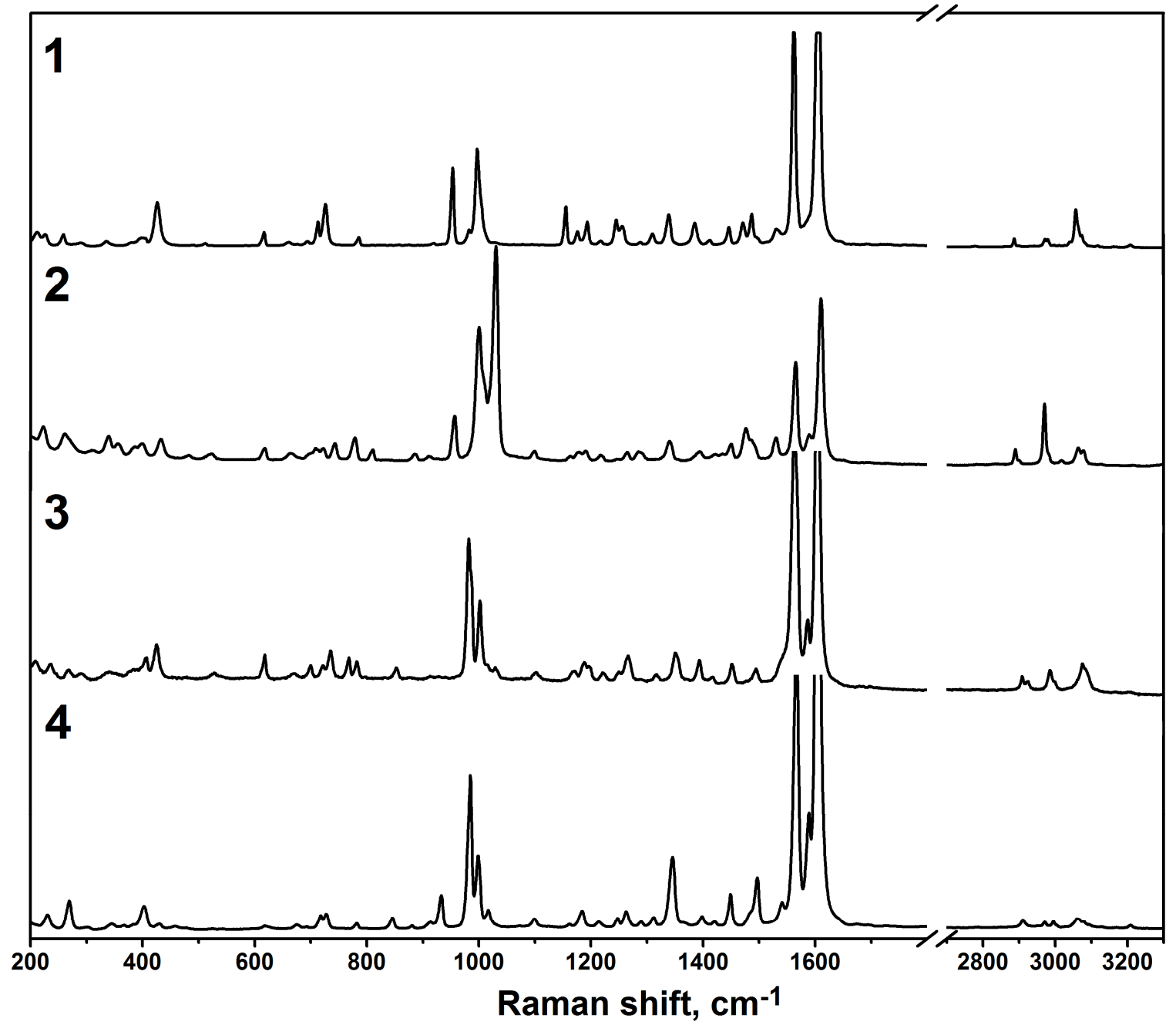

Figure 7. Raman spectra recorded on single crystals of $\mathbf{1 , 2 , 3}$ and $\mathbf{4}$. The region $1700-2700 \mathrm{~cm}^{-1}$ is removed due to the absence of bands.

\section{Conclusions}

We have synthesized and determined the crystal structures of four new $\pi$-compounds with 2 (allylthio)-5-phenyl-1,3,4-oxadiazole (Atphod), namely $\quad\left[\mathrm{Cu}_{2}(\text { Atphod })_{2} \mathrm{Br}_{1.91} \mathrm{Cl}_{0.09}\right]$ $\left[\mathrm{Cu}(\right.$ Atphod $\left.) \mathrm{NO}_{3}\right](\mathbf{2}),\left[\mathrm{Cu}_{2}(\text { Atphod })_{2}\left(\mathrm{H}_{2} \mathrm{O}\right)_{2}\right]\left(\mathrm{BF}_{4}\right)_{2}(\mathbf{3})$ and $\left[\mathrm{Cu}_{2}(\text { Atphod })_{2}\left(\mathrm{H}_{2} \mathrm{O}\right)_{2}\right]\left(\mathrm{ClO}_{4}\right)_{2}(\mathbf{4})$. These compounds are the first-known $\pi$-complexes bearing the 1,3,4-oxadiazole core bound to a $\mathrm{Cu}(\mathrm{I})$ ion. The Atphod ligand in 1-4 acts as a chelate $\pi, \sigma$-ligand, being attached to the $\mathrm{Cu}(\mathrm{I})$ ion by means of an allylic $\mathrm{C}=\mathrm{C}$ bond and one or two oxadiazole $\mathrm{N}$ atoms. In the presence of $\mathrm{BF}_{4}{ }^{-}$and $\mathrm{ClO}_{4}{ }^{-}$anions, the copper(I) ion acts as a bridge, connecting two neighboring Atphod molecules into a $\left[\mathrm{Cu}_{2}(\text { Atphod })_{2}\left(\mathrm{H}_{2} \mathrm{O}\right)_{2}\right]^{2+}$ dimeric tecton, each of which is bound with $\mathrm{H}_{2} \mathrm{O}$ molecules in various 
ways, most likely due to the different H-bonded arrays in the structure. Two bridging halogen atoms in 1 connect the $[\mathrm{Cu}(\text { Atphod })]^{+}$units into a centrosymmetric fragment with a $\left[-\mathrm{N},(\mathrm{C}=\mathrm{C}) \mathrm{Cl}_{2}-\right]$ coordination topology of $\mathrm{CuX}(\mathrm{X}=\mathrm{Cl}$ or $\mathrm{Br})$, previously observed for 7 copper-olefine compounds. The structures of $\mathbf{2}$ and $\mathbf{4}$ were found to be the first-known examples of $\mathrm{CuNO}_{3}$ and $\mathrm{CuClO}_{4}$ coordination with a 1,3,4-oxadiazole ring. Taking into account one more weakly coordinated nitrate $\mathrm{O}$ atom $\left(\mathrm{Cu}-\mathrm{O} 2.598(3) \AA\right.$ ) in 2 , the $[\mathrm{Cu}(\text { Atphod })]^{+}$fragments are bound by means of bringing $\mathrm{NO}_{3}{ }^{-}$ anions into a 1D-polymer. To analyze the interactions between the molecules in $\mathbf{3}$ and $\mathbf{4}$, Raman spectroscopy accompanied by computational modelling at the DFT/B3LYP/cc-pVDZ level was used for the vibrational spectral analyses and band assignments.

\section{Appendix A. Supplementary data}

CCDC 1531990, 1531991, 1531992 and 1531993 contain the supplementary crystallographic data for compounds $1,2,3$ and 4 , respectively. These data can be obtained free of charge via http://www.ccdc.cam.ac.uk/conts/retrieving.html, or from the Cambridge Crystallographic Data Centre, 12 Union Road, Cambridge CB2 1EZ, UK; fax: (+44) 1223-336-033; or e-mail: deposit@ccdc.cam.ac.uk.

A comparison of the experimental and calculated geometries and details of the experimental and computed Raman spectra are also available in the Supplementary data.

\section{Acknowledgments}

E.G would like to acknowledge the financial support by Slovenian Research Agency (ARRS), program P1-0045.

\section{References}

[1] C.H. Ding, X.L. Hou, 4.11 Nucleophiles with Allyl Metal Complexes A2 - Knochel, Paul, in: Comprehensive Organic Synthesis II (Second Edition), Elsevier, Amsterdam, 2014, pp. 648-698. [2] W. Bensch, Modern Inorganic Synthetic Chemistry. Edited by Ruren Xu, Wenqin Pang and Qisheng Huo, Angewandte Chemie International Edition, 51 (2012) 305a-307.

[3] R.C. Mehrotra, Organometallic Chemistry, New Age International (P) Limited, 2007.

[4] A. Sivaramakrishna, H.S. Clayton, M.M. Mogorosi, J.R. Moss, Coord. Chem. Rev., 254 (2010) 2904-2932.

[5] Y. Slyvka, E. Goreshnik, O. Pavlyuk, M. Mys'kiv, Cent. Eur. J. Chem., 11 (2013) 1875-1901.

[6] E.A. Goreshnik, Y.I. Slyvka, M.G. Mys'kiv, Inorg. Chim. Acta, 377 (2011) 177-180.

[7] Y.I. Slyvka, E.A. Goreshnik, B.R. Ardan, G. Veryasov, D. Morozov, M.G. Mys'kiv, J. Mol. Struct., 1086 (2015) 125-130. 
[8] G. Prakash, R. Ramachandran, M. Nirmala, P. Viswanathamurthi, J. Sanmartin, Inorg. Chim. Acta, 427 (2015) 203-210.

[9] M. Singh, R.J. Butcher, N.K. Singh, Polyhedron, 27 (2008) 3151-3159.

[10] S. Juan, A.M. Jigar, Z. Hai-Liang, Mini-Rev. Med. Chem., 13 (2013) 1725-1743.

[11] J. Suwiński, W. Szczepankiewicz, 5.06 - 1,3,4-Oxadiazoles A2 - Katritzky, Alan R, in: C.A. Ramsden, E.F.V. Scriven, R.J.K. Taylor (Eds.) Comprehensive Heterocyclic Chemistry III, Elsevier, Oxford, 2008, pp. 397-466.

[12] C.R. Groom, I.J. Bruno, M.P. Lightfoot, S.C. Ward, Acta Crystallogr. Sect. B, 72 (2016) 171 179.

[13] E. Hoggarth, J. Chem. Soc. (Resumed), (1952) 4811-4817.

[14] E.A. Goreshnik, V.V. Olijnyk, V.K. Pecharsky, M.G. Mys'kiv, Russ. J. Inorg. Chem., 39 (1994) 71-76.

[15] E.A. Goreshnik, D. Schollmeyer, M.G. Myskiv, Z. Anorg. Allg. Chem., 628 (2002) 21182122.

[16] A.A. Shkurenko, V.N. Davydov, M.G. Mys'kiv, Russ. J. Coord. Chem., 32 (2006) 270-275.

[17] Y. Slyvka, N. Pokhodylo, R. Savka, Z. Mazej, E. Goreshnik, M. Mys'kiv, Chem. Met. Alloys, 3 (2010) 201-207.

[18] E.A. Goreshnik, M.G. Mys'kiv, J. Chem. Crystallogr., 4 (2010) 381-383.

[19] B. Ardan, Y. Slyvka, E. Goreshnik, M. Mys'kiv, Acta Chim. Slov., 60 (2013) 484-490.

[20] E. Goreshnik, G. Veryasov, D. Morozov, M. Mys'kiv, J. Mol. Struct., 1038 (2013) 200-205.

[21] E. Goreshnik, G. Veryasov, D. Morozov, Y. Slyvka, B. Ardan, M. Mys' kiv, J.Organomet. Chem., 810 (2016) 1-11.

[22] Agilent Technologies, CrysAlisPro, Version 1.171.37.31 (release 14-01-2014 CrysAlis171 .NET)

[23] G. Sheldrick, Acta Crystallogr. Sect. C, 71 (2015) 3-8.

[24] G. Sheldrick, Acta Crystallogr. Sect. A, 64 (2008) 112-122.

[25] O.V. Dolomanov, L.J. Bourhis, R.J. Gildea, J.A.K. Howard, H. Puschmann, J.Appl.

Crystallogr., 42 (2009) 339-341.

[26] A.D. Becke, J. Chem. Phys., 98 (1993) 5648-5652.

[27] C. Lee, W. Yang, R. Parr, Phys. Rev. B, 37 (1988) 785-789.

[28] M.W. Schmidt, K.K. Baldridge, J.A. Boatz, S.T. Elbert, M.S. Gordon, J.H. Jensen, S. Koseki, N. Matsunaga, K.A. Nguyen, S. Su, T.L. Windus, M. Dupuis, J.A. Montgomery, J. Comput. Chem., 14 (1993) 1347-1363.

[29] P.L. Polavarapu, J. Phys. Chem., 94 (1990) 8106-8112. 
[30] G. Keresztury, S. Holly, G. Besenyei, J. Varga, A. Wang, J.R. Durig, Spectrochim. Acta Part A 49 (1993) 2007-2026.

[31] A. Bondi, J. Phys. Chem., 70 (1966) 3006-3007.

[32] A. Bondi, J. Phys. Chem., 68 (1964) 441-451.

[33] S. Alvarez, Dalton Trans., 42 (2013) 8617-8636.

[34] A. Albinati, M.L. Carraro, S. Gross, M. Rancan, S. Rizzato, E. Tondello, A. Venzo, Eur. J. Inorg. Chem., 2009 (2009) 5346-5351.

[35] K. Fukushima, A. Kobayashi, T. Miyamoto, Y. Sasaki, Bull. Chem. Soc. Jpn., 49 (1976) 143.

[36] T. Dużak, B. Zarychta, V. Olijnyk, Z. Anorg. Allg. Chem., 640 (2014) 57-62.

[37] Y.E. Filinchuk, M.G. Mys'kiv, V.N. Davydov, Russ. J. Coord. Chem., 24 (1998) 771.

[38] J.L. Duncan, Mol. Phys., 28 (1974) 1177-1191.

[39] R.J. van der Wal, A. Vos, Acta Crystallogr. Sect. B, 38 (1982) 2318-2320.

[40] X.-H. Bu, H. Liu, M. Du, L. Zhang, Y.-M. Guo, M. Shionoya, J. Ribas, Inorg. Chem., 41 (2002) 1855-1861.

[41] P. Gómez-Saiz, J. García-Tojal, M.A. Maestro, J. Mahía, F.J. Arnáiz, T. Rojo, Polyhedron, 21 (2002) 2257-2263.

[42] A.W. Addison, T.N. Rao, J. Reedijk, J. van Rijn, G.C. Verschoor, J. Chem. Soc., Dalton Trans., (1984) 1349-1356.

[43] S.W. Kelemu, P.J. Steel, Allylureas, Cryst. Growth Des., 14 (2014) 1245-1250.

[44] S.W. Kelemu, P.J. Steel, CrystEngComm, 15 (2013) 9064-9071.

[45] Y. Slyvka, N. Pokhodylo, R. Savka, E. Goreshnik, Z. Mazej, Chem. Met. Alloys, 2 (2009) 130137.

[46] J. Chen, C.-P. Li, J. Shang, M. Du, Inorg. Chem. Commun., 15 (2012) 172-175. 


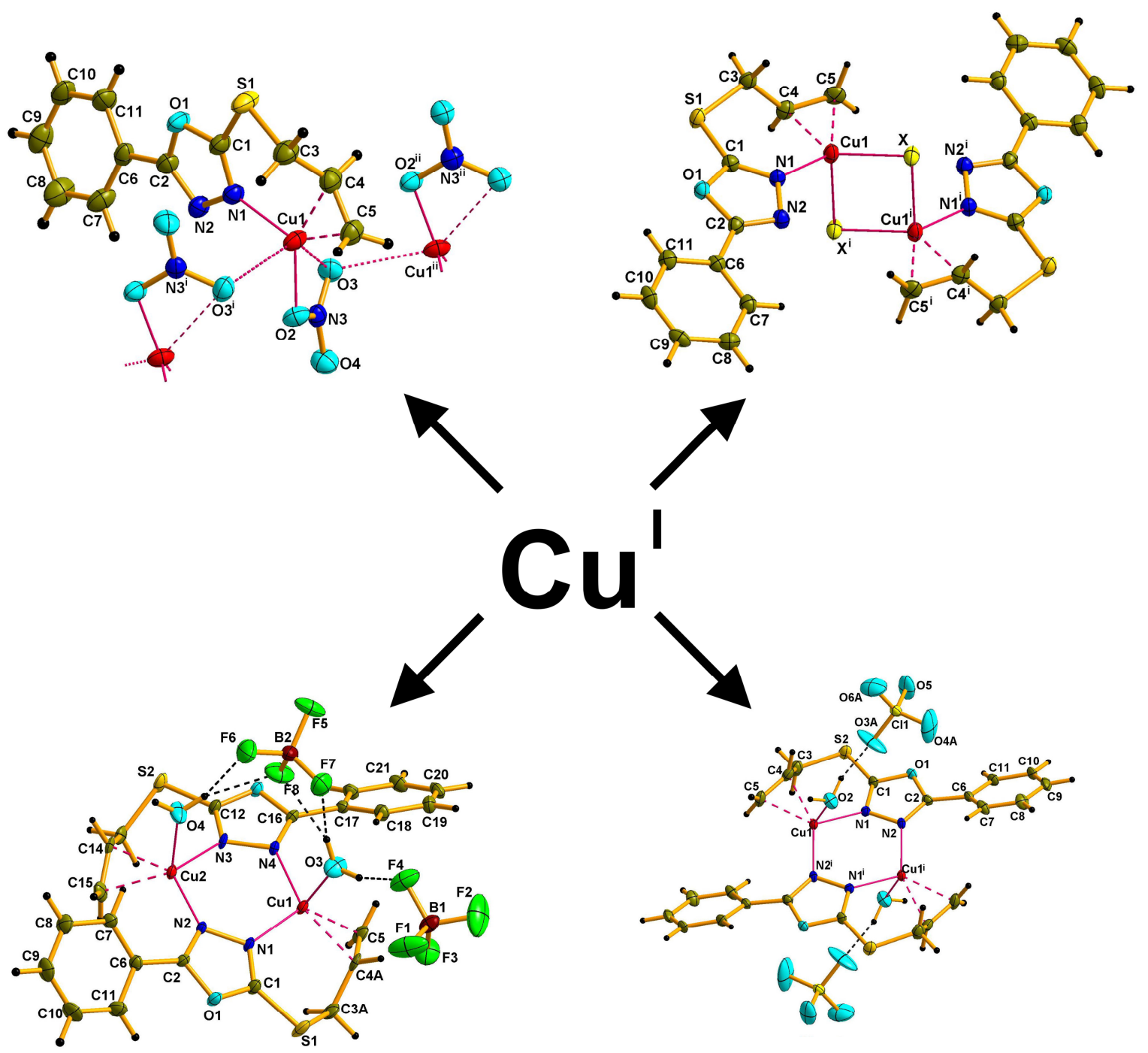


Using the alternating-current electrochemical technique and starting from copper(II) salts and the 2(allylthio)-5-phenyl-1,3,4-oxadiazole ligand, four new $\pi$-complexes were obtained. All the compounds were characterized by single crystal X-ray diffraction and Raman spectroscopy. The molecular structures and Raman spectra of the compounds were computed using the DFT/B3LYP/cc-pVDZ level of theory. 